\title{
Doing the right thing: Measuring wellbeing for public policy
}

\author{
Marie J. C. Forgeard · Eranda Jayawickreme · Margaret L. Kern • \\ Martin E. P. Seligman
}

\begin{abstract}
Many experts now recognize that income is not a measure that alone captures the wellbeing of individuals, and governments around the world are starting to rethink the ways in which they measure the welfare of their citizens. Wellbeing is best understood as a multifaceted phenomenon that can be assessed by measuring a wide array of subjective and objective constructs. This review summarizes the state of research on the various domains of wellbeing measured by psychologists and social scientists, and provides an overview of the main theoretical perspectives that integrate these domains. Among these theoretical perspectives, we highlight Well-being Theory, which decomposes the wellbeing construct into five domains: Positive emotion, Engagement, Relationships, Meaning, and Accomplishment (PERMA). We conclude by formulating recommendations for future research on the measurement of wellbeing. These recommendations include the need to combine both objective and subjective indicators, and the use of a dashboard approach to measurement. This approach conveys the multifaceted nature of wellbeing and will help policy-makers and citizens understand which domains of wellbeing should constitute priorities for public policy.
\end{abstract}

Keywords: well-being, wellbeing, public policy, measurement, wellbeing theory

\section{Introduction}

"What you measure affects what you do. If you don't measure the right thing, you don't do the right thing." The words of Nobel prize-winning economist Joseph Stiglitz (as cited by Goodman, 2009, para. 3) capture the growing discontentment of citizens, academics, and policy-makers toward the way most governments define and measure progress - namely, by emphasizing economic indicators such as Gross Domestic Product (GDP) (e.g., Abramovitz, Scitovsky, \& Inkeles, 1973; Layard, 2005; Zencey, 2009). Among others, Layard (2010) recently challenged policy-makers to think about what 'progress' really is and how it can best be measured. From its beginnings in the 1930s, the history of national accounts in the United States shows that the wellbeing of citizens, not the wellbeing of their bank accounts, was considered to be the end goal of government (Perlman \& Marietta, 2005). The economist Simon Kuznets (1933), the first promoter of national accounts in the United States, argued that the goal of collecting economic information (e.g., income distribution, growth, productivity) was to examine how those indicators influence the welfare of the nation. Kuznets however also acknowledged that economic indicators were but one piece of the puzzle of citizens' wellbeing, and that "the welfare of a nation can [...] scarcely be inferred from a measurement of national income" (Kuznets, 1934, p. 7). After the Second World War, Kuznets (1948) denounced the 
resulting increase in focus of national accounts on economic production, to the detriment of other measures of welfare. In spite of his critique, the use of economic indicators as proxies for wellbeing became conventional practice for the rest of the twentieth century. As pointed out by the economist Partha Dasgupta (2001), "GNP per capita continues to be regarded as the quintessential indicator of a country's living standard" (p. 53).

Recent years have seen renewed interest in the idea that money and economic growth are both insufficient and inadequate indicators of progress, especially in developed countries. Nations have become increasingly prosperous over the past five decades, yet wealth has become an increasingly inadequate indicator of how a society is doing. As a result, there are now "distressingly large, measurable slippages between economic indicators and well-being" (Diener \& Seligman, 2004, p. 1). For illustration, even though GDP has tripled over the past 50 years in the United States, life satisfaction has remained unchanged (Diener \& Seligman, 2004). In contrast, rates of depression and anxiety have increased dramatically (Klerman et al., 1985; Robins et al., 1984; Twenge, 2000). The overabundance of goods and services available in developed nations therefore does not reflect the subjective wellbeing of their citizens, a situation that has been described as "the progress paradox" (Easterbrook, 2003).

Even the manner in which GDP is calculated makes it an inappropriate measure of wellbeing. Indeed, GDP is inflated by "regrettables" (Diener \& Seligman, 2004), i.e., economic transactions that create wealth but decrease wellbeing. To illustrate, the GDP of a nation increases with each sale of antidepressant medication, with each divorce pronounced, and with each prison built. U.S. presidential candidate Robert Kennedy (1968, para. 22) perhaps best summed up the inadequacy of economic growth as a surrogate for wellbeing:

The Gross National Product counts air pollution and cigarette advertising, and ambulances to clear our highways of carnage. It counts special locks for our doors and the jails for the people who break them [...] It counts the destruction of the redwood and the loss of our natural wonder in chaotic sprawl [...] Yet the GNP does not allow for the health of our children, the quality of their education, or the joy of their play. It does not include the beauty of our poetry or the strength of our marriages, the intelligence of our public debate or the integrity of our public officials [...] it measures everything, in short, except that which makes life worthwhile.

Spearheading the movement to reform the way in which governments measure progress, the UK-based New Economics Foundation recently proposed the National Accounts of WellBeing initiative (Michaelson, Abdallah, Steuer, Thompson, \& Marks, 2009). Referring to Kuznets' unfinished endeavor (Kuznets, 1933; Perlman \& Marietta, 2005) and highlighting the fact that the end goal of national accounts should be citizens' wellbeing (not the size of their wallets), the creators of the National Accounts of Well-Being explained that their initiative represents "a return to the original intent for modern national accounting systems" (Michaelson et al., 2009, p. 11). A poll conducted in the United Kingdom revealed that $81 \%$ of respondents believed the government's primary goal should be the "greatest happiness" rather than the "greatest wealth" (Easton, 2006). In France, the report of the Commission on the Measurement of Economic Performance and Social Progress (CMEPSP) initiated by French president Nicolas Sarkozy stated that "the time is ripe for our measurement system to shift in emphasis from measuring economic production to measuring people's well-being. [...] Emphasizing well-being is important because there appears to be an increasing gap between 
the information contained in aggregate GDP data and what counts for common people's wellbeing" (Stiglitz, Sen, \& Fitoussi, 2009, p. 12). Thus, there is a growing consensus around the need to measure wellbeing at a national level and to have this construct serve as an end goal of national public policy (Sketekee, 2011; Wardell, 2010).

While there is a growing agreement that measures of wellbeing should be included, the issue of how wellbeing should be defined and measured remains unresolved (Smith, Fleeson, Geiselmann, Settersten, \& Kunzmann, 2001). As a result, a large diversity of definitions exist (Gasper, 2010). Most researchers now agree that wellbeing is a multifaceted construct (e.g., Diener, 2009; Michaelson, et al., 2009; Stiglitz, et al., 2009), including emotional, social, and functional components, yet disagreements persist as to which components should be included in a valid theory and measure of wellbeing (Diener, Scollon, \& Lucas, 2003). Diener and Seligman (2004) pointed out that a more systematic approach is needed, as the "current measurement of well-being is haphazard, with different studies assessing different concepts in different ways" (p. 2). The multiplicity of approaches in the study of wellbeing has given rise to blurred and overly broad definitions of wellbeing, with researchers using the construct of 'wellbeing' synonymously with 'happiness,' 'quality of life,' or 'life satisfaction.' Furthermore, some researchers have preferred to ignore the multifaceted nature of wellbeing and equate it with one construct (often life satisfaction), leading to the unfortunate omission of other important aspects of wellbeing. As a result, Gasper (2004) argued that new measures need to respect the diversity of wellbeing.

The present review summarizes the state of research on the measurement of wellbeing and highlights potential opportunities and pitfalls in the development of new instruments and theoretical approaches. In Section 2, we provide an overview of tools that have been used to measure subjective facets of wellbeing (e.g. positive emotion, engagement, meaning, life satisfaction, relationships/social support, and accomplishment/competence). In Section 3, we discuss objective theories and social indicators of wellbeing, as well as the debate surrounding the need to integrate subjective and objective measures of wellbeing. Section 4 examines how current measures fit with existing psychological theories, including Well-being Theory (Seligman, 2011), and ends with a proposal for a new approach to the measurement of wellbeing: the dashboard approach.

\section{Subjective measures of wellbeing}

We begin with a brief overview of the main instruments used by researchers to measure subjective facets of wellbeing, to lay a foundation for the theories detailed in Section 4 . This non-exhaustive summary highlights the constructs that have received the most attention in the literature and therefore does not include all possible aspects of wellbeing that researchers have considered (see Gasper, 2010; and Jayawickreme \& Seligman, 2010 for more comprehensive reviews). In addition, we note that we are not recommending a particular measure; some of the most common measures have received strong criticism, and researchers should carefully consider relevant literature in choosing to use one or more measure.

\subsection{Happiness}

A rather straightforward and therefore intuitively appealing measurement of wellbeing consists of simply asking people whether they are "happy." Fordyce's Happiness Measures (Fordyce, 1988) for instance asks respondents to answer the question "In general, how happy or unhappy do you usually feel?" using an 11-point Likert scale. The measure also asks participants to indicate the percentage of time they usually feel happy, unhappy, and neutral 
(neither happy nor unhappy). Similarly, Lyubomirsky and Lepper's Subjective Happiness Scale (SHS; 1999) asks respondents to indicate on a 7-point Likert scale if they generally consider themselves to be "not a very happy person / a very happy person." The SHS also asks respondents to compare themselves to others in terms of happiness (e.g., "compared to most of my peers, I consider myself: less happy / more happy"). While directly asking individuals about their happiness certainly has face validity, it remains unclear what information respondents use to determine whether or not they are happy. Happiness is therefore an unwieldy construct for scientific research (Seligman, 2011), and researchers have devoted their efforts to decomposing this vague notion of "happiness" into more basic and quantifiable, building blocks.

\subsection{Positive emotion}

Positive emotion is one of the most studied facets of wellbeing, perhaps because it possesses high face validity, offers a conceptual complement to the large literature on negative emotion, and has high intuitive appeal. The intuitive correspondence most people establish between positive emotion and wellbeing is partially derived from the philosophy of hedonism, which suggested that pleasure is the only thing that is good for us, whereas pain is the only thing that is bad (Bentham, 1789/1996) - a view which has been referred to as "narrow hedonism" (Parfit, 1984). Empirically, researchers interested in the measurement of positive emotion have included a broader and more nuanced range of positive and negative emotional states besides pleasure and pain. For instance, the Positive and Negative Affect Schedule (PANAS; Watson, Clark, \& Tellegen, 1988), one of the most widely-used measures of positive and negative emotions, asks respondents to rate how much they are feeling 10 positive emotions (e.g., "excited," or "alert") and 10 negative emotions (e.g., "upset," or "ashamed") in a timeframe specified by experimenters (e.g., "in general," "during the past two weeks"). Similarly, Bradburn's Affect Balance Scale (1969) assesses individuals' level of positive and negative emotions. This 10-item self-report scale asks respondents to answer 10 questions about ways they may have felt over the past week (e.g, "during the past week, did you ever feel pleased about having accomplished something?" and "during the past week, did you ever feel upset because someone criticized you?").

Recently, Diener and colleagues developed the Scale of Positive and Negative Experience (SPANE; Diener et al., 2010), designed to address some of the flaws in previous measures of positive and negative emotions. The SPANE is a 12-item self-report measure that asks respondents to indicate how much they have experienced 12 general feelings (e.g., "pleasant," "joyful") as opposed to the more narrow feelings described by the PANAS or Bradburn's Affect Balance Scale. Specific feelings used in other scales may bias results if they do not correspond to the particular states experienced by respondents, if respondents have difficulty labeling specific feelings, or if some of the feelings valued by other cultures are omitted in the scale. The PANAS has been criticized for only including high arousal emotions; the SPANE therefore includes both low and high arousal emotions. Finally, the SPANE asks respondents to indicate how much of the time they experienced particular feelings (as opposed to how intensely they experienced them), a question which is more highly correlated with other facets of wellbeing such as life satisfaction (Diener, Sandvik, \& Pavot, 1991).

One problem with retrospective self-report instruments used to assess positive emotions is that individuals may use the way they feel at the moment they are answering to determine how they have felt over a longer period of time (especially if the questionnaire calls for a longer timeframe). Respondents may also be subject to memory biases, such as the tendency to recall 
the most salient and last experience best (Kahneman, 1999). Researchers interested in measuring positive emotion as accurately as possible have therefore developed methods other than the standard self-report questionnaires. One example is the Day Reconstruction Method (DRM), used to measure the frequency and intensity of a variety of positive and negative emotions over time (Kahneman, Krueger, Schkade, Schwarz, \& Stone, 2004). With the DRM, individuals are asked to list all of the activities they engaged in during a period of 24 hours, and then rate those activities according to the positive and negative emotions they afforded. While the DRM remains a retrospective method, it allows for more fine-grained data regarding individuals' sum-total of positive and negative emotions. Researchers can calculate individuals' levels of positive emotion by adding up the total of those momentary positive emotions and subtracting the total momentary negative emotions (Kahneman, 1999).

In addition to the DRM, researchers have also used the Experience Sampling Method (ESM; Csikszentmihalyi, Larson, \& Prescott, 1977; for reviews, see Hektner, Schmidt, \& Csikszentmihalyi, 2007; Scollon, Kim-Prieto, \& Diener, 2007) to improve accuracy in reports of positive and negative emotions. In ESM, respondents are signaled ('beeped') via electronic devices (e.g., pager, mobile phone) at random intervals during the day and are asked to answer questions regarding how they are feeling right at that moment. A typical ESM study lasts one to two weeks, with individuals responding to around two to twelve signals per week (Fleeson, 2007; Reis \& Gable, 2000). ESM has a number of advantages (Furr, 2009; Scollon, et al., 2007). First, ESM has high ecological validity because it allows individuals to answer questions while involved in real-life situations. Second, it prevents the memory biases associated with retrospective methods by asking respondents to describe their emotions on the spot. Third, it allows for better examination of within-person fluctuations in emotions. Finally, even though ESM started as a costly and time-consuming method, the advent of new technologies has made it increasingly easy to use and increasingly cost-effective. For example, ESM can now be implemented using applications for cellular phones.

ESM however also has a number of drawbacks (Scollon et al., 2007). First, the time commitment required from participants may encourage self-selection and attrition issues. Typical ESM participants may therefore be more motivated, conscientious, and agreeable than average. Second, the technology involved may prevent certain groups with low familiarity or resources to participate. Third, participants may decide not to respond during particular activities, thus impinging on the randomness of sampling. Fourth, participants may react to the measure, changing the phenomenon studied (Wheeler \& Reis, 1991). The issue of reactivity is inherent to ESM, as this technique interrupts participants' experiences ("I was feeling good until they beeped me"), and may make them more aware of how they tend to respond ("I guess I must be a sad person"). Finally, ESM generates massive amounts of data that researchers must be prepared to aggregate and analyze in meaningful ways, as the basic data management and statistical techniques that are typically used in psychological studies may be insufficient. This issue is more of a challenge than a real drawback for researchers, given the richness of the data provided by ESM.

The DRM and ESM are techniques that allow for richer data than can be provided by ordinary self-report questionnaires administered at one or two points in time. Both methods have been used to assess positive emotions, but they need not be limited to this construct. ESM, for instance, was originally developed to measure engagement, the next facet of wellbeing that we discuss.

Research on the measurement of positive emotion has therefore yielded several useful instruments and methods. However, the question of the role that positive emotion should play 
in a valid measure of wellbeing remains debated. Some theories (reviewed in Section 4) view positive emotion as central to wellbeing, whereas other approaches (such as eudaimonic accounts of wellbeing) dismiss it. One important consideration is that individuals are not equally endowed with the ability to experience positive emotion. Introverts, for instance, are much less likely than extraverts to experience positive emotion (Hills \& Argyle, 2001). As a result, interventions that are designed to boost positive emotion will do so more easily in extraverts, and measurements of positive emotion will favor extraverts over introverts. Policymakers may therefore end up unintentionally over-counting what works for extraverts and discounting what works for introverts. The fairness of using positive emotion as a main metric for wellbeing is therefore disputable, and it might be more fruitful to focus on the measurement and cultivation of other facets of wellbeing (Seligman, 2011).

\subsection{Engagement}

Engagement refers to a psychological state in which individuals report being absorbed by and focused on what they are doing. At its high end, engagement has been referred to as "flow" (Csikszentmihalyi, 1996), or the overall feeling referred to as "being in the zone." According to Csikszentmihalyi (1996, 1975), high levels of engagement are characterized by the following characteristics: the individual has clear goals and is intrinsically interested in the task at hand; the task presents challenges that meet the skill level of the individual; the task provides direct and immediate feedback to the individual; the individual retains a sense of personal control over the activity; and action and awareness become merged, such that the individual becomes completely immersed in what he or she is doing.

Few measures of engagement exist, and this construct is not usually represented in largescale surveys of wellbeing. As previously mentioned, the Experience Sampling Method (ESM) was used by Csikszentmihalyi and colleagues to examine instances of flow as closely as possible to the time they occurred (Csikszentmihalyi, Rathunde, \& Whalen, 1997; Larson \& Csikszentmihalyi, 1983). When signaled, participants were typically asked to fill out a questionnaire describing (among other things) what they were doing, and why they were doing it (e.g., "I had to," "I wanted to"). Participants were also asked to rate their activity on various dimensions of flow (e.g., concentration, self-awareness, sense of control, challenges and skills, intrinsic interest). This methodology allowed the researchers to look at the experience of engagement and flow in relation to the development of talent in adolescent populations. Aside from ESM, the Flow Scale (Csikszenmihalyi \& Csikszenmihalyi, 1988; Mayers, 1978) has also been used to assess the level of engagement experienced during various activities. This scale is an 11-item self-report measure in which respondents rate statements in relationship to a specific situation (e.g., "I feel I can handle the demands of the situation," "I clearly know what I am supposed to do"). The administration of this questionnaire is often preceded by having participants read three statements describing the kinds of experience people report when they are in flow, so that they can familiarize themselves with this concept (e.g., "I am so involved in what I am doing, I don't see myself as separate from what I am doing.") (Csikszentmihalyi, 1975). Apart from flow experiences, alternative measures of engagement are lacking.

\subsection{Meaning and purpose}

Meaning has been defined in various ways: as "the ontological significance of life from the point of view of the experiencing individual" (Crumbauch \& Maholick, 1964, p. 201), as the "feeling of belonging and serving something larger than the self" (Seligman, 2011), or simply as the response to the question "what does my life mean?" (e.g., Baumeister, 1992). 
The study of meaning was prevalent in early humanistic tradition (Frankl, 1959; Maslow, 1968; Yalom, 1980) but was largely ignored in psychology over the past fifty years due to lack of empirical evidence. Psychologists have however returned to the topic in recent years (Baumeister, 1992; King, Hicks, Krull, \& Gaiso, 2006; Park, 2010; Ryff, 1989; Seligman, 2002), partially through the advent of positive psychology. In particular, meaning is now viewed as an essential contributor to overall wellbeing that is separate from, but positively correlated with, other facets of wellbeing (Chamberlain \& Zika, 1992; King, et al., 2006; Locke \& Latham, 2002; Seligman, 2002). For example, social activists high in moral excellence report high levels of meaning stemming from their work (Colby \& Damon, 1992). In keeping with this conceptualization, McGregor and Little (1989), in a factor analysis of wellbeing measures, found that meaning and happiness are distinct constructs. For example, having children may decrease happiness among parents, but contributes very significantly to their levels of meaning (Baumeister, 1992). Nussbaum (2007) also presented the case of the misanthropic Northern Irish politician David Trimble (who shared the 1998 Nobel Peace Prize) as an example illustrating the possibility of having a meaning-rich life that is not necessarily filled with positive emotion.

In spite of the recent resurgence of interest in the construct of meaning, there are few instruments to measure it. Steger, Frazier, Oishi, and Kaler's (2006) Meaning in Life Questionnaire measures both the subjective presence of meaning and the subjective search for meaning. Respondents are asked to rate ten statements on a 7-point Likert scale (e.g., "My life has a clear sense of purpose;" "I am searching for meaning in my life"). In addition, measures of spirituality and/or religious faith (e.g., Seidlitz et al., 2002; Worthington et al., 2003) may tap into the construct of meaning in life as they connect individuals with higher purposes.

\subsection{Life satisfaction}

Perhaps the most widely used type of measures to assess wellbeing are measures of life satisfaction, in which participants are asked to answer the question "How satisfied are you with your life?" This type of question is different from asking individuals how they are "feeling" because it tries to appeal to more reflective and evaluative aspects in considering one's life. Shin and Johnson (1978) defined life satisfaction as "a global assessment of a person's quality of life according to his chosen criteria" (p. 478). Life satisfaction judgments therefore depend on the standards individuals have set for themselves. Individuals with similar objective circumstances may judge their lives to be more or less satisfying, a problem that has led many to advocate for the use of more objective measures of wellbeing.

Life satisfaction questions have been included in many large-scale international surveys, but often use only one question in order to assess citizens' wellbeing. This is for example the case of the Household Income and Labor Dynamics in Australia Survey (HILDA; Watson, 2005), the British Household Panel Study (BHPS; University of Essex, 2008), and the German Socio-Economic Panel Study (GSOEP; German Institute for Economic Research, 2008), among other surveys. One-item measures are problematic, as any response to a question contains some amount of error. By using multiple items, the size of this error can be reduced and the measurement made more reliable. In order to address this problem, the National Accounts of Well-Being (Michaelson, et al., 2009) include four items pertaining to life satisfaction. In addition, Diener, Emmons, Larsen and Griffin developed the Satisfaction with Life Scale (SWLS; 1985), a self-report questionnaire that asks respondents to rate five statements concerning their present satisfaction with life (e.g., "So far, I have gotten the important things I want in life") on a 7-point scale. Another version of the SWLS, the Temporal Satisfaction with 
Life Scale (Pavot, Diener, \& Suh, 1998), assesses respondents' past, present, and future life satisfaction by asking them to rate 15 statements.

The use of life satisfaction measures as a surrogate for wellbeing has been criticized on various grounds (for a review, see Kahneman \& Krueger, 2006). Paralleling critiques of positive emotion, some researchers have criticized measures of life satisfaction because respondents may often use how good they feel at the moment they are asked as the basis for the judgment they are making. Measures of life satisfaction may therefore be contaminated by mood (Schwarz \& Strack, 1999). In addition, the order and context in which questions are presented may have important effects on results. For example, in a study by Strack and colleagues (Strack, Martin, \& Schwarz, 1988), the relation between the number of dates a student had in the past month and his or her life satisfaction was significant only when the dating question was asked before the life satisfaction question, indicating a priming effect.

These and other similar results (e.g., Schwarz \& Clore, 1983) suggest that answers to life satisfaction questions may be constructed by respondents based on different pieces of information, including immediate context (Schwarz \& Strack, 1999), as well as conventional indicators of one's achievements, such as income (Kahneman, Krueger, Schkade, Schwarz, \& Stone, 2006). In response to these findings, some researchers have sought to determine under which conditions life satisfaction may be affected by mood and other contextual effects. Pavot and Diener (1993) for instance found that the contamination of life satisfaction judgments by mood occurs mostly for single-item measures, but not for multiple-item instruments such as the Satisfaction with Life Scale (SWLS).

Another criticism of life satisfaction measures is that they may be biased by respondents' social desirability (Carstensen \& Cone, 1983). Social desirability however probably constitutes a personality characteristic that enhances wellbeing. Research by Diener and colleagues has shown that important information is lost when social desirability is removed from life satisfaction measures (Diener, Sandvik, Pavot, \& Gallagher, 1991). There is therefore danger in changing the construct of interest by controlling for personality-type characteristics.

Perhaps the biggest problem with life satisfaction measures is that this construct has too often been equated to overall wellbeing, leading researchers to ignore other facets. As noted by Michaelson and colleagues, "it is all very well knowing that someone is satisfied with their life, but the interesting question is why" (2009, p. 56). The only way to answer this question is to look at other facets of wellbeing as well.

Other researchers have also advocated for the use of both life satisfaction and emotion information to assess overall subjective wellbeing. These researchers argued that a more complete assessment of an individual's life incorporates both life satisfaction along with momentary feelings (Dolan, Peasgood, \& White, 2006). Such evaluative accounts incorporate both our hedonic experiences (momentary emotions) alongside our cognitive assessments of how well life is going more generally. Since both of these elements are subjective, this kind of account is termed subjective wellbeing (SWB), an umbrella term combining how we think plus how we feel about our lives (Diener et al., 1999).

\subsection{Relationships and social support}

Social support-the belief that one is cared for, loved, esteemed and valued-has been recognized as one of the most (if not the most) influential determinants of wellbeing for people of all ages and cultures (Reis \& Gable, 2003). Numerous measures of social support and positive relationships have been developed as a result, and most large-scale surveys examining wellbeing integrate questions on this topic. For instance, the World Health Organization 100 
survey (WHOQOL-100; Bonomi, Patrick, Bushnell, \& Martin, 2000) asks an array of questions such as "How satisfied are you with the support you get from your friends?" and "Do you feel happy about your relationships with your family members?" The Oxford Poverty and Human Development Initiative's Missing Dimensions of Poverty Relatedness module (Samman, 2007) similarly asks participants to rate three statements pertaining to social support (e.g., "People in my life care about me"). The New Economics Foundation's National Accounts of Well-Being (Michaelson, et al., 2009) also has two sections related to social support: Supportive Relationships (e.g., "Do you have anyone with whom you can discuss intimate and personal matters") and Trust and Belonging (e.g., "To what extent do you feel like people in your area help one another?").

An exhaustive review of all existing psychological measures of relationships and social support is beyond the scope of this article (for reviews, see Cohen, Underwood, \& Gottlieb, 2000; Gottlieb \& Bergen, 2010; Orth-Gomér \& Undén, 1987), although a few instruments are worth mentioning to illustrate various approaches to measuring social support. Three measures in particular have been used in a large number of studies and have been recommended by other authors for their robust psychometric properties (Gottlieb \& Bergen, 2010). First, the ENRICHD Social Support Inventory (ESSI; Mitchell et al., 2003) is a 7-item measure assessing the availability of a network member to provide emotional, informational, as well as practical support. The ESSI was originally designed for use with a medical population (i.e., patients recovering from myocardial infarction). Second, the Social Provisions Scale (SPS; Cutrona \& Russell, 1987) is a 24-item measure of perceived support divided into three assistance-related (i.e., reassurance of worth, guidance, reliable alliance) and three non-assistance related (i.e., opportunity for nurturance, attachment, and social integration) functions. Finally, the Inventory of Socially Supportive Behaviors (ISSB; Barrera, Sandler, \& Ramsay, 1981) is a 40item measure of support that asks respondents to indicate how often they were at the receiving end of socially supportive behaviors during the preceding month, using a 5-point Likert scale (e.g., "Did some activity together to help you get your mind off things," "Let you know that you did something well"). By asking about actual events (as opposed to perceived support), the ISSB intends to be more objective, although some authors have argued that objective received support may improve wellbeing only insofar as it contributes to perceived support (for a review of the relationship between received and perceived support, see Haber, Cohen, Lucas, \& Baltes, 2007). The ISSB nevertheless illustrates the question of whether subjective measures should be complemented with objective measures when possible, which we address in Section 3.

\subsection{Accomplishment and competence}

Accomplishment can be defined in terms of achievement, success, or mastery at the highest level possible within a particular domain (Ericsson, 2002). In some domains such as sports, business, or education, accomplishment is measured through agreed-upon standards, such as competitions (e.g., gold medals at the Olympics), honors and awards (e.g., winning the Nobel Peace Prize), scholastic achievement tests (e.g., performance on the SAT), or reaching a particular level (e.g., president or CEO of an organization). At the individual level, accomplishment can be defined in terms of reaching a desired state and progress toward prestated goals (Heckhausen, Wrosch, \& Schultz, 2010; Negru, 2008). Competence, a closely related construct, has been defined as the sense of efficacy individuals have regarding their internal and external environments (Ryan, Huta, \& Deci, 2008), and is one of the three basic 
psychological needs posited by Deci and Ryan's (2000) Self-Determination Theory (detailed in Section 4).

As a result of the growing recognition of the human need for accomplishment (Seligman, 2011), some large-scale surveys of wellbeing have incorporated items tapping accomplishment and competence. The Oxford Poverty and Human Development Initiative's Missing Dimensions of Poverty Competence module (Samman, 2007) asks participants to rate three statements related to competence (e.g., "Most of the time I feel a sense of accomplishment from what I do" and "I generally feel very capable"). The New Economics Foundation's National Accounts of Well-Being (Michaelson, et al., 2009) also has two questions ("Most days I feel a sense of accomplishment from what I do" and "In my daily life I get very little chance to show how capable I am"). Finally, the Purpose in Life subscale of Ryff's Psychological Well-Being Scales (Ryff, 1989) includes items relevant to accomplishment and competence (e.g., "I enjoy making plans for the future and working to make them a reality").

\section{Objective measures of wellbeing}

As a result of the large body of research that has accumulated on how to measure wellbeing and in conjunction with the growing discontentment that surrounds the use of economic growth as our main metric for progress, many researchers and policy-makers have called for the development of national indicators of wellbeing that will achieve the conceptual and methodological sophistication of national economic indicators. Several conceptual issues described here underlie the enterprise of creating such indices. To assist researchers in developing national indicators of wellbeing, Diener (2006) proposed guidelines for their creation. He recommended that (1) the various facets of wellbeing be measured separately; (2) instruments sensitive to fluctuation in wellbeing resulting from changes in circumstances be utilized; (3) short-term and long-term changes in wellbeing be assessed separately; and (4) instruments measuring wellbeing be psychometrically valid (that is, that they consistently measure what they are supposed to be measuring). Diener also pointed out that current instruments, although comparatively imperfect, can still provide information to policy-makers that standard economic indicators cannot offer.

\subsection{Objective theories of wellbeing}

Several "objective-lists" or "needing" accounts have been advocated over the last sixty years (Ranis, Stewart, \& Samman, 2006). These accounts propose that wellbeing should be measured using lists of objective indicators, and the crucial issue is how to choose which indicators should be included. In a review of the literature, Alkire (2002) noted 39 different attempts at defining what makes a 'good' or 'flourishing' life between 1938 and 2000. While a detailed review of this literature will not be attempted here, Ranis and colleagues (2006) summarized several accounts worth mentioning, each of which adopts a different conceptual approach and justification.

First, Amartya Sen's (1999) capabilities approach, perhaps the best-known needs-based account of wellbeing in the social sciences, posited a framework that focuses on the extent to which individuals can function successfully with the goods that they have at hand. In setting up this framework, Sen distinguished between 'functionings' and 'capability' (Sen, 1999). 'Functionings' (the core notion in his account) refer to the various activities that an individual may value doing, while that individual's 'capability' consists of "the alternative combinations of functionings that are feasible for her to achieve" (p. 75). One's capability is therefore a form of freedom, as it affords the opportunity to achieve multiple combinations of functionings. 
Related to Sen's theory, Nussbaum (2000) spelled out a substantive list of ten capabilities (life, bodily health and integrity, senses/imagination/thought, emotions, practical reason, affiliation, living in relation with other species, play, and control over one's environment) which, while non-exhaustive, are non-negotiable in their equal worth, as they are together constitutive of what it means to achieve "truly human functioning" (Nussbaum, 2006, p. 71).

Second, Rawls (1971/1999) identified a set of primary goods that "are in general necessary for the framing and execution of a rational plan of life" (p. 359): rights, liberties, opportunities, income and wealth, as well as the social bases of self-respect. Rawls identified these goods through a process of deliberative rationality, defined as "a careful consideration of the relevant facts and after a careful consideration of the consequences" (p. 380). Finnis and colleagues (Finnis, 1980; Finnis, Boyle, \& Grisez, 1987) used an approach similar to Rawls' to define a list of goods (i.e., life, knowledge, play, aesthetic experience, sociability and friendship, practical reasonableness, and religion). Unlike Rawls' approach, which sees primary goods as necessary requirements for the good life, Finnis described his goods as constitutive elements of a flourishing existence, such that wellbeing is defined in terms of these goods.

Third, Doyal and Gough's (1991) Basic Needs Approach is founded on the negative principle of "do no harm," where harm is defined as factors that prevent individuals from realizing activities central to their life plan. Doyal and Gough suggested that health and autonomy constitute the most basic needs for individuals of all cultures, and proposed the following second-order needs in order to achieve health and autonomy: nutritional food and clean water, adequate housing, a safe work environment, health care, security in childhood, close relationships, physical security, economic security, education, as well as safe birth control and childbearing.

Among other approaches worth mentioning is Narayan-Parker's (2000) Voices of the Poor analysis, which lists needs identified by the poor. These needs have been collected through focus groups with individuals in the developing world. Finally, Camfield's (2005) Economic and Social Research Council Research Group of Well-Being in Developing Countries attempts to collect information on how individuals perceive wellbeing in four separate nations.

The need-based theories described here catalogue the objective list of goods required for 'wellbeing,' or a 'happy' life. Dolan and colleagues (2006) argued that objective list accounts do not provide a formal theory of wellbeing; rather, they offer a list of attributes and characteristics which are taken to constitute wellbeing. The contents of the lists vary but tend to include items such as economic resources, political freedom, good health, and the ability to read. Needing accounts may therefore not provide complete theories of wellbeing, but they suggest what the essential means for increasing wellbeing might be.

Dolan and colleagues (2006) also argued that the presence or absence of certain objective attributes may lead to more subjective satisfaction for individuals, but the value of these objective attributes should be independent of these consequent effects. Therefore, the judgment about the contribution of various needs (e.g., education, health, etc.) towards wellbeing does not come from the individual, but draws on theoretical and intuitive accounts of what societies value. Thus, this approach holds that "certain things are good or bad for beings, independently in at least some cases of whether they are desired or whether they give rise to pleasurable experiences" (Chappell \& Crisp, 1998, p. 553).

While some of these objective standards may be confirmed using a subjective perspective (i.e., do individuals report that an objective condition has increased or decreased their wellbeing?), their validity for wellbeing should be determined externally. This approach was grand-fathered by Aristotle's flourishing account of wellbeing. Aristotle proposed a 
perfectionist version of wellbeing, in which the wellbeing of an individual is judged by considering how close they are to reaching the potential of humankind. Aristotle's term for this, "eudaimonia," has been translated into various terms, including "flourishing," "happiness," or "wellbeing." To help human beings flourish (i.e., realize their potential) is the Aristotelian justification for the items on the objective list.

\subsection{Objective social indicators}

Many scientists in fields other than psychology have conceptualized wellbeing as a set of objective conditions. Starting in the 1960s, social scientists began to think about the objective standards by which people's quality of life, other than economic growth, can be evaluated, as such standards "assess where we stand and are going with respect to our values and goals" (Bauer, 1966, p.1, as cited by Land, 1996). Social indicators therefore attempt to track and evaluate objective aspects of citizens' wellbeing in target societies (Diener, Lucas, Schimmack, \& Helliwell, 2009; Gasper, 2010) and provide guidance on how to improve. These social indicators are often also referred to as quality-of-life indicators or key national indicators (Diener et al., 2009). The working assumption behind social indicators is that a comprehensive set of indicators can be identified that captures an objective conception of wellbeing (Dolan \& White, 2007).

One example of an indicator set is the list of Key National Indicators proposed by the United States General Accounting Office (GAO, 2003), which comprises ten indicators in each of eight different domains. Examples of domains assessed include social indicators related to the community (e.g., rates of volunteering or homelessness), education (e.g., percentage of adults having completed postsecondary education), health (e.g., life expectancy, physical activity), and social support (e.g., percentage of elderly individuals living alone and in poverty).

Another well-known set of social indicators used to measure wellbeing is the Human Development Index (HDI), developed by the United Nations Development Program (UNDP, 2010). The HDI is based on Amartya Sen's (1999) theoretical work on important capabilities required for an individual to achieve optimal functioning. In its most recent version (UNDP, 2010), the HDI operationalizes wellbeing using three main dimensions: longevity and health (i.e., life expectancy at birth), access to knowledge (i.e., mean years of schooling and expected years of schooling) and a decent standard of living (i.e., Gross National Income per capita, adjusted for purchasing power). A national version of the HDI has also been created for the United States (Lewis \& Burd-Sharps, 2010).

\subsection{Concerns about objective wellbeing measures}

Wellbeing researchers have identified a number of concerns about using objective indicators as sole measures of wellbeing (Diener, Lucas, Schimmack, \& Helliwell, 2009). First, it is not intuitively obvious which items should be included in a finite set of domains that contribute to, or constitute, wellbeing. It is not clear whether domains included on existing lists are necessarily important for overall wellbeing. Diener et al. (2009) noted the example of number of hobbies, included in the Living Conditions Index of the Netherlands (Boelhouwer \& Stoop, 1999), speculating that many people engage in a variety of meaningful activities that they do not call hobbies. Conversely, important items that should reasonably be included on any exhaustive list may end up being omitted. For example, child mortality may be included on a list whereas care for the elderly may not. 
Second, it is questionable how to best operationalize objective domains of flourishing. We may be interested in measuring engagement with culture, but does that entail giving equal status to attendance at the opera and at professional wrestling matches? Who should decide which activities are included? Such subjective decision-making may compromise the ostensibly objective nature of the indicators. Moreover, Gasper $(2004,2010)$ noted that objective measures of wellbeing such as social indicators are necessarily rooted in values, highlighting the fact that any list of indicators reflects to some degree the values of the list's compilers, as well as the values of the communities under assessment. As Phillips (2006, as cited by Gasper, 2010) suggested, we might be better off calling these supposedly objective measures "collectively subjective measures" (p. 33). As a result, Diener (1995) proposed a values-based approach for identifying social indicators that are prized within particular societies, so that progress in valued domains can be accurately tracked (Diener et al., 2009). According to Diener, using values as the basis for inclusion of particular indicators may help solve the problem that indicators have tended to be selected in a rather unsystematic manner. In keeping with this approach, Diener developed new measures of quality of life (the Basic and Advanced Quality of Life indices) based on the universal values previously described by Schwartz (1992).

Third, the accuracy of objective measures needs to be considered. One argument that is frequently deployed in favor of objective measures of wellbeing is that they can be clearly observed and empirically verified (Diener et al., 2009). While this should be true in principle, the objective data that is frequently cited may not always be accurate. For example, variations in cultural norms about the appropriateness of suicide may lead to the underreporting of suicide-related deaths (Diener et al., 2009; Rockett \& Thomas, 1999). Additionally, the specific meaning of objective indicators may vary across nations and cultures. For example, ten years of schooling in one country may not mean the same or be comparable as ten years in another country. More broadly, the needs of a particular target individual may not always match the standards and criteria of an observer (Smith et al., 2001). Such differences limit the value of cross-national comparisons. Diener and colleagues (2009) also noted that similar scores on a specific indicator could reflect different levels of wellbeing. For example, a strong police force in an area may reflect either high drug use, or a well-functioning government, or an overbearing commitment to law and order.

A fourth issue involves identifying the optimal levels of specific indicators (for example, should additional resources be allocated to increase life expectancy, even if it means prolonging the lives of people in extremely poor health?) and the sensitivity of such indicators across the range of measurement units, given that useful indicators should reveal movement when societal progress has been made (Diener et al., 2009). One problem with measures such as the Human Development Index (which measures longevity, education and income) is that all the industrialized nations cluster relatively closely together with little real difference between them. Even if these countries do not differ on longevity, education and income, they may however still differ significantly on other important indicators.

A final issue involves the integration of these indicators and the appropriate weights to be used. Which of the indicators should be weighted more heavily? Who decides which ones are more important? How does one weigh education against health care? Such issues are unavoidable, and have not to date been resolved satisfactorily (Diener et al., 2009).

\subsection{Combining objective and subjective wellbeing measures}

While objective approaches share a common general goal with subjective approaches - a richer understanding of what it means to live well - Comim (2005), writing specifically of the links 
between the subjective and objective approaches (in particular, the capabilities approach), noted that the "seemingly obvious overlap in their object of research does not seem to be accompanied by any considerable acknowledgement of the vast work that has been produced in the two fields" (p. 162). With regards to similarities between objective and subjective measurement of wellbeing, Comin (2005) identified a number of prominent similarities between the objective capabilities approach and subjective accounts.

First, both accounts have a similar core objective - an investigation of wellbeing and how people evaluate their lives. Diener (2000), Sen (1999) and Nussbaum $(2006,2000)$ made similar claims, and the two approaches can be seen as constituting distinctive informational spaces within the study of wellbeing. Second, both approaches rely (directly or indirectly) on individuals' own evaluation of their own wellbeing. While this is fundamentally constitutive of the subjective approach, Sen $(1999,2004)$ emphasized the importance of public deliberation in discussing the relevant capabilities or objective needs, while Nussbaum's later work (2000, 2006) emphasized the value of pluralism and consensus in how her capabilities are understood. Third, both approaches distinguish between means and ends, and give priority to a direct assessment of ends. While this is a hallmark of the capabilities approach, Diener and Seligman (2004) also made the Aristotelian claim that "money [...] is a means to an end, and that end is well-being." As a result, they concluded "After all, if economic and other policies are important because they will in the end increase well-being, why not assess well-being directly?" (p. 2).

Fourth, both the objective and subjective approaches attack and offer themselves as alternatives to simple resource-based and preference-based accounts of wellbeing. Fifth, both the objective and subjective approaches value democratic participation. Sen (1999) saw this as a valuable end in itself, while subjective wellbeing researchers place more emphasis on its instrumental effect on wellbeing. Sixth, both approaches emphasize the importance of autonomy and self-determination. Nussbaum (2006) noted that the capabilities approach "stresses the animal and material underpinnings of human freedom, and it also recognizes a wider range of types of beings who can be free" (p. 88). For Sen (1999), having positive freedoms is constitutive of development. Subjective wellbeing researchers (and positive psychologists in general) have stressed the importance of autonomy and control. As Ryan and Deci (2006) noted: "Autonomy is a salient issue across development, life concerns, and cultures, and is of central importance for personality functioning and wellness" (p. 1580).

Seventh, both approaches consider the role of emotions in assessing wellbeing. Positive and negative emotions are constitutive of the subjective approach (Diener, 2006; Diener, Oishi, \& Lucas, 2003), while Nussbaum $(2000,2001)$ has argued that emotions play an important role in shaping individuals' choices. Eighth, both advocate for methodological pluralism. Diener (2006) for instance has argued for measuring multiple aspects of subjective wellbeing. Similarly, a hallmark of a number of objective approaches is their focus on multiple informational spaces. Ninth, both approaches recognize the dangers of adaptive preferences, which could potentially bias individuals' evaluation of their own wellbeing. Nussbaum (1997) characterizes adaptation as "a phenomenon in which an individual shapes her preferences to accord with the (frequently narrow) set of opportunities she actually has" (p. 218). Capability advocates have used this argument as evidence against the subjective wellbeing approach, and Diener (2000; 2003) has acknowledged that self-report measures of wellbeing can be tainted by this problem. As a result, Diener and colleagues (2003) advocated for the development of other, more accurate measures to measure mood states.

One obvious issue in attempting to reconcile these approaches is that subjective approaches focus on mental states, while objective indicators of wellbeing do not. In fact, many positive 
psychologists have acknowledged that subjective reports of wellbeing are susceptible to adaptive preferences, and that "we probably need to take into account more objective bases for judging the attainment of the good life [such as Nussbaum and Sen's work]" (Peterson, 2006, p. 312). ${ }^{1}$

Individuals' subjective preferences may, however, not necessarily contradict objective conceptions of wellbeing. Sen (1993) argued that this would be the case as long as positional parameters (that is, individual characteristics of a person and his position in the world that impacts his observations) that affect individuals' cognitions are accounted for, so that particular types of "special mental tendencies" (p. 137) can be excluded. Similarly, Nussbaum (2000) advocated for what she calls an "intelligently normative proceduralism" (p. 159), in which preferences are evaluated with a view towards discarding those that are mistaken or illegitimate. She later noted: "Convergence between the best informed desire approach and the capabilities approach should give us confidence that we are on the right track" (Nussbaum, 2006, p. 81).

Rawls (1971/1999; 2001) similarly explained that happiness has two aspects: the successful execution of a rational life plan, and that individual's state of mind. Happiness can therefore be defined either objectively or subjectively. Objectively, happiness involves "a certain achievement in action and a rational assurance about the outcome," whereas subjectively it involves the belief that the plan is being successfully executed (p. 481). For Rawls, a complete life plan includes multiple ends, as well as due considerations of rights and justice (p. 482), and "happiness is an inclusive end, meaning that the plan itself, the realization of which makes one happy, includes and orders a plurality of aims, whatever they are" (p. 484-485). Whereas Rawls' account of the good life is strongly normative, his claim that happiness entails a plurality of aims appeals to both subjective and objective accounts (Comim, 2005).

\section{Psychological theories of wellbeing}

Some researchers (e.g., Layard, 2005; Veenhoven, 2004) have argued that the improvement of single constructs such as happiness or life satisfaction can be a valuable end for governments to pursue, and that it can in some instances be justified as the ultimate end of public policy. We note however that while subjective measures can provide important information that can inform policy decisions, they are not meant to override other sources of information, such as objective measures of wellbeing and standard economic indicators. We therefore recognize the value of multiple informational spaces in assessing wellbeing, an insight that is shared by a number of theoretical approaches in psychology outlined below. As an exhaustive description of existing theories of wellbeing is beyond the scope of this review, we focus on a subset of approaches that aptly explain how particular combinations of wellbeing facets can guide our understanding and measurement of wellbeing as a whole, and ultimately, interventions to increase it.

\subsection{The psychological wellbeing tradition}

The Psychological Wellbeing Tradition (PWB; Ryff, 1989, 1995; Ryff \& Keyes, 1995; Ryff \& Singer, 1998, 2002) arose as a complementary approach to the subjective wellbeing (SWB) perspective. While the SWB perspective does not specify a single conception of wellbeingpreferring instead to leave such matters to the individual - the PWB perspective adopts a more

\footnotetext{
${ }^{1}$ However, individuals do not completely adapt their preferences in response to certain life events, such as disabilities (Lucas, Clark, Georgellis, \& Diener, 2004).
} 
theory-guided approach to wellbeing, arguing that focusing solely on affect and life satisfaction neglects important aspects of positive psychological functioning (Ryff, 1989).

Ryff's (1989) definition of psychological wellbeing combines insight from three domains of psychological theory: personal growth models, life-span development perspectives, and positive mental health. First, personal growth models include Jung's (1933) notion of individuation, Allport's (1961) conception of maturity, Rogers' (1962) theory of the fullyfunctioning individual, as well as Maslow's (1968) notion of self-actualization. Second, life-span development perspectives include Bühler's (1935) basic life tendencies towards life-fulfillment, Erikson's (1959) psychosocial stage model, and Neugarten's $(1968,1973)$ perspectives on personality change in adulthood and old age. Finally, Jahoda's (1958) positive mental health model provided a detailed description of what constitutes psychological health, which is characterized by efficient self-perception, realistic self-esteem and acceptance, control over behavior, accurate perception of the world, sustained relationships, and self-direction.

Ryff's resulting PWB perspective was intended to provide a parsimonious and empirically robust conception of wellbeing derived from the theoretical perspectives noted above. This conception contains six dimensions: (1) self-acceptance, manifested by holding positive attitudes towards oneself and one's past life; (2) positive relations with others that are warm and trusting; (3) autonomy, which is reflected by qualities such as self-determination, independence, selfregulation of behavior, and an internal locus of evaluation; (4) environmental mastery, defined as the ability to choose and/or create environments suitable to one's psychic condition; (5) purpose in life, or having beliefs that give the individual the feeling that there is purpose in and meaning to life; and (6) personal growth, manifested as developing one's potential, as well as growing and expanding as a person. These six dimensions can be assessed using the Psychological WellBeing Scales (Ryff \& Keyes, 1995). The PWB account differs from the SWB account primarily in its focus on eudaimonic facets of wellbeing and its omission of hedonic components such as positive emotion. According to the PWB perspective, human flourishing is characterized by "doing and living well" rather than "feeling good."

A large body of research has examined the psychosocial, socio-demographic and biological correlates of PWB. For example, Helson and Srivastava (2001) utilized the domains of personal growth (PG) and environmental mastery (EM) to identify three configurations of positive human development: Achievers (high on PG and EM), Conservers (high on EM, low on PG), and Seekers (high on PG, low on EM). Other research programs have focused on the relation between PWB and psychological constructs such as personality traits (Lopes, Salovey, \& Straus, 2003), coping strategies (Kling, Seltzer, \& Ryff, 1997), personal goals (Riediger \& Freund, 2004) and self-enhancing cognitions (Taylor, Lerner, Sherman, Sage, \& McDowell, 2003). Ryff and Singer (1996) also found significant age differences in profiles of positive functioning in crosssectional studies. Specifically, environmental mastery and autonomy showed incremental patterns from young adulthood to midlife, whereas personal growth and purpose in life presented a decremental pattern from midlife to old age. Positive relations and self-acceptance, on the other hand, did not show significant changes across the lifespan. In addition, Ryff and Singer (1998) have used the PWB account as the basis of a research program assessing the physiological substrates of the dimensions of wellbeing. According to Ryff and Singer, this approach constitutes the greatest hope for understanding the biology of what they term positive human health, as well as the processes that sustain resilience in the face of illness and disease.

Keyes, Shmotkin, and Ryff (2002) argued that while PWB and SWB dimensions are related to each other, they remain empirically distinct. Specifically, they found that in a sample drawn for the national Midlife in the U.S. (MIDUS) survey, the best fitting model was one that posited 
SWB and PWB as two correlated latent constructs. This view ties in with lay conceptions of happiness (which is part of SWB) and meaning (which is part of $\mathrm{PWB}$ ) as separate components of the good life (King \& Napa, 1998). Keyes and colleagues (2002) also found that the probability of achieving high levels of both SWB and PWB increased as age, education, extraversion, and conscientiousness increased and as neuroticism decreased. When compared with adults who had higher levels of SWB than PWB, adults with higher levels of PWB were younger, had more education, and showed more openness to experience.

\subsection{Need satisfaction and self-determination theory}

While the ideals described above define wellbeing from a PWB perspective, Ryan and Deci's (2000) Self Determination Theory (SDT) defines three psychological needs that are principal predictors of wellbeing: autonomy, competence, and relatedness. The need for autonomy refers to a feeling of choice and volition in the regulation of behavior. The need for relatedness refers to the importance of feeling cared for and closely connected to others. The need for competence refers to the sense of efficacy individuals hold with regards to internal and external environments (Ryan, Huta, \& Deci, 2008). These needs have been shown to be cross-culturally valued (Sheldon, Elliot, Kim \& Kasser, 2001) and relate to measures of subjective wellbeing (Reis, Sheldon, Gable, Roscoe, \& Ryan, 2000; Sheldon, Ryan, \& Reis, 1996).

SDT has its origins in Deci and Ryan's (1980) work on intrinsic motivation - the pursuit of an activity for its own sake, interest, and rewards. Intrinsic motivation is contrasted with extrinsic motivation, which refers to the pursuit of activities for instrumental ends. Deci and Ryan (1985) described the process through which extrinsic goals come to be assimilated and accommodated, or internalized. By examining the determinants and consequences of pursuing various goals, they established directions between aspirations based on their content. Kasser and Ryan (1996) for instance found that life goals could be differentiated into those relating to intrinsic aspirations (including growth, affiliation, community contributions, and health) and those relating to extrinsic aspirations (wealth, fame, image, etc.). Their study built on earlier research showing that individuals who had strong aspirations for financial success had lower levels of wellbeing, compared to individuals who had strong aspirations for relationship growth and community (Kasser \& Ryan, 1993). These findings led Ryan, Sheldon, Kasser and Deci (1996) to posit that the key difference between intrinsic and extrinsic aspirations is their ability to fulfill basic psychological needs.

One distinctive claim made by self-determination theorists is that these three basic psychological needs are related to intrinsic values that are an essential part of human nature. (They are careful however to point out that this short list is not exhaustive). These three needs are nonetheless essential for the development of intrinsic aspirations and psychological wellbeing (Kasser \& Ryan, 1996). Moreover, SDT hypothesizes that attaining intrinsic goals will lead to the satisfaction of these psychological needs. Cultivating, pursuing, and reaching such goals therefore constitutes a privileged path to increase wellbeing. According to SDT, the satisfaction of the basic psychological needs of autonomy, relatedness, and competence therefore mediates the relation between intrinsic goal attainment and wellbeing (Ryan, Huta, \& Deci, 2008).

In addition to examining the content and nature of individuals' goals, self-determination theorists have stressed the importance of understanding the reasons why individuals pursue important goals (Ryan \& Deci, 2000). A sub-theory of SDT, organismic integration theory (OIT; Deci \& Ryan, 1985) distinguished between intrinsic motivation (the most autonomous form of regulation, as described above), amotivation (the state of lacking the intention to act) and 
different forms of extrinsic motivation, which differ in the extent to which regulation is autonomous. On this account, the most heteronomous form of regulation is external regulation. An example of such regulation would be an individual acting to avoid pain or gain a reward. A second form of external motivation is introjected regulation. This involves accepting a motivation but not completely seeing it as one's own. In other words, one may retain an externally perceived locus of causality, although the motivation may be internally driven. In this form of regulation, behavior is performed for the purpose of avoiding guilt or anxiety, or to attain feelings of pride or self-esteem. A third and significantly more self-determined form of extrinsic motivation is identified motivation, which involves the conscious and explicit valuing of a behavioral goal or regulation, leading to that goal being seen as personally important. The fourth and most autonomous form of extrinsic motivation is integrated motivation, where identified regulations are fully assimilated and brought to congruence with an individual's other values.

The relative autonomy of goals (including extrinsic goals) appears to have effects that are independent of the content of the goal on wellbeing (Sheldon, Ryan, Deci, \& Kasser, 2004). For example, Ryan and Connell (1989) found that, in a sample of schoolchildren, identified regulation was related to higher levels of interest and enjoyment, greater levels of effort, and more positive coping styles, than less autonomous forms of regulation. Subsequent studies have linked autonomous forms of motivation to a range of good outcomes including increased levels of physical activity, political activity, behavioural effectiveness, volitional persistence, and subjective well-being, and greater assimilation within a social group (Chatzisarantis, Biddle, \& Meek, 1997; Koestner, Losier, Vallerand, \& Carducci, 1996; Ryan, Kuhl, \& Deci, 1997; Williams, Rodin, Ryan, Grolnick, \& Deci, 1998). The OIT sub-theory also proposes that the basic psychological needs of autonomy, competence, and relatedness are important for the nurturing of internalization and integration. For example, with regards to the role of relatedness, Ryan, Stiller, and Lynch (1994) found that children who were securely connected to and cared for by their teachers and parents had more fully internalized the regulation for positive school-related behaviors. Thus, these needs are believed to play an important role in the successful regulation and integration of behavior, and thwarting these needs may be psychologically harmful.

\subsection{Well-being Theory and the dashboard approach to measurement}

According to Seligman (2011), the notion of 'happiness' is an unwieldy construct that hides the true multifaceted nature of human flourishing. Happiness may constitute the overarching goal of positive psychology, but it does not play any part in a valid and useful theory of human wellbeing. In the first version of his theory, Seligman (2002) claimed that 'happiness' was composed of three subjective facets: positive emotion, engagement, and meaning. Happiness was therefore achievable by pursuing one or more of these facets. As a result, individuals low in one aspect could still be 'happy' if they nurtured other components. Individuals low in positive emotions could, for instance, flourish by being highly engaged in their lives, or by cultivating a rich sense of meaning.

Seligman (2011) recently revised his original theory by adding two facets to his original account: positive relationships and accomplishment. In addition, Seligman redefined the endpoint of his theory as "well-being" rather than "happiness" in order to stress the multifaceted nature of human flourishing, and to prevent the usual confusion that is often made between 'happiness' and 'cheerfulness.' Seligman's new theory therefore posits that wellbeing consists of the nurturing of one or more of the five following elements: Positive emotion, Engagement, Relationships, Meaning, and Accomplishment (abbreviated as the 
acronym PERMA). These five elements are the best approximation of what humans pursue for their own sake, which is why they have a place in Well-being Theory. Although individuals may sometimes pursue these elements for other ends (e.g., they may for instance think that accomplishment will bring positive emotion), many choose to do so because these elements are intrinsically motivating by themselves.

Seligman's theory also reconciles differing perspectives on the theory and measurement of wellbeing by including both hedonic and eudaimonic aspects of wellbeing, and by allowing for (and encouraging) the measurement of each element using both objective and subjective approaches. Such measures are currently being developed. In addition, measurements of PERMA need to examine how the various facets of wellbeing need to be weighted if researchers or policy-makers want to be able to come up with a single summary measure.

The issue of how to integrate various measures of wellbeing facets into an overall composite index of wellbeing is an engaging one for researchers. An examination of this question however leads us to propose that such an index may not be as useful as it seems, in spite of its intuitive appeal. Why do we want one number to summarize the wellbeing of an individual, a family, or community, or a nation? Perhaps it is because a single number satisfies our craving for simple findings and conclusions, in spite of the complexity of the phenomena being studied. Being able to say that one country has the highest level of wellbeing in the world does make for an appealing headline, but it also provides a poor description of the nature of this country's flourishing. Just as we do not have a single indicator telling us how our car is performing (instead, we have an odometer, a speedometer, a gas gauge, etc.), we suggest that we do not want just one indicator of how well people are doing. We want to be able to look at a 'dashboard' of measures and indicators that can help us understand our strengths, as well as the particular areas in which we may not be fulfilling our potential for flourishing.

Thus, we recommend that future measures of wellbeing present their results in a way that takes advantage of the variety of constructs that are measured. This approach can further be enhanced through visualization tools, making such a measure intuitively understandable. Rather than making decisions based on averages on a single measure, functioning across multiple domains can be charted. Research studies can empirically examine what types of profiles lead to different outcomes. Decision makers can visually examine different profiles and determine what areas are doing well and what areas should be targeted, based on cultural values, thus allowing for cultural variation informed by universal measures. Such efforts are already underway, as seen in the New Economics Foundation National Accounts of Well-Being (Michaelson et al., 2009), which used data from the European Social Survey's Personal and Social Well-Being Module (Huppert et al., 2006). The module was administered to around 43,000 adults (above 16 years old) in twenty-three countries of the European Union. Wellbeing was decomposed into nine components (positive feelings, absence of negative feelings, life satisfaction, vitality, resilience and self-esteem, positive functioning, supportive relationships, as well as trust and belonging), and the researchers then visually represented the performance of various European countries on these facets of wellbeing using multi-axis plots (spiderweb plots), thus presenting the data in all of its richness. The module included both how people feel and how they function, thus drawing upon both the hedonic and eudaimonic perspectives on wellbeing. Following collection of the data, Huppert and So (2009) derived an empirical definition of flourishing by looking at the percentage of respondents of the United Kingdom who endorsed the three core facets of wellbeing (positive emotion, engagement, meaning) as well as any three additional facets (any combination of self-esteem, resilience, positive relationships, and optimism). There were widely varying rates of flourishing throughout 
Europe, with the highest rate found in Denmark (33\%) and northern Europe in general, and the lowest rates found in Russia (6\%), and Eastern Europe in general. Aside from between-nations differences, higher flourishing was associated with higher education levels, higher income, general health, and being married. Flourishing was found to decline with age, although not linearly so. Indeed, people over sixty-five years of age in certain countries (for instance, Ireland) show the highest rates of flourishing, whereas middle-aged people showed the lowest rates. In addition, flourishing correlated with life satisfaction only modestly $(r=.32)$, providing support to the notion that measures of life satisfaction (a unitary construct) are not adequate to assess wellbeing (a multifaceted construct).

\section{Conclusions and future directions}

The present review summarized the state of research on the measurement of wellbeing, as well as the theories that underlie differing approaches to measurement. Section 2 reviewed the ways in which scientists have operationalized wellbeing, namely in terms of happiness, positive emotion, engagement, meaning/purpose, life satisfaction, relationships/social support, and accomplishment/competence. Section 3 discussed theories and indices attempting to objectively assess wellbeing, highlighting the question of accuracy and both the advantages and challenges presented by the possibility of combining both subjective and objective measures of wellbeing. Section 4 presented the main theories of wellbeing, which propose different ways to combine facets of wellbeing in order to best capture human flourishing.

The first conclusion that can be drawn from this review is that numerous advances have already been made in the measurement of wellbeing, and scientists are well on their way to constructing useful measures that are solidly grounded in theory. Among these advances is the work of Huppert and colleagues (Huppert et al., 2008; Huppert and So, 2009; Michaelson et al., 2009), who proposed a promising approach to measure various facets of wellbeing, as well as to present data in a way that allows for a nuanced understanding of the complex nature of wellbeing. According to this group of researchers, wellbeing can be defined as a "dynamic process that gives people a sense of how their lives are going through the interaction between their circumstances, activities, and psychological resources" (Michaelson et al., 2009, p. 3). The work of Lyubomirsky and colleagues (Luybomirsky, 2008; Lyubomirsky, Sheldon, \& Schkade, 2005) suggests that intentional activities (i.e., active efforts by individuals) account for $40 \%$ of the variance in wellbeing in developed countries, approximately four times as much as external circumstances do. These findings support conceptualizing wellbeing as an active process.

Another promising avenue of research for scientists who are interested in the measurement of wellbeing involves the harnessing of new technologies. Information found on the internet, including websites fostering communication and personal expression (e.g., Facebook, Twitter, etc.) constitute goldmines of information on citizens' subjective feelings, and the years ahead will probably see a surge of scientific research on how to best exploit these data.

A second conclusion that can be drawn from this review is that future research on the measurement of wellbeing should strive to capture the multifaceted and dynamic nature of wellbeing. We suggest that future assessments should combine both objective and subjective measures of wellbeing, in order to provide the full picture of human flourishing. Subjective measures appear to be indispensable insofar as the presence of objective conditions of wellbeing may not always be accompanied with subjective feelings of wellbeing (as pointed out by the high rates of Major Depressive Disorders in developed countries). Yet subjective measures are insufficient; objective measures provide essential additional information by conveying the circumstances in which individuals live and develop. Furthermore, the question 
of whether wellbeing should be conceptualized and measured as a subjective or objective phenomenon should be solved by thinking about the following question outlined by Layard (2010): what is progress; how do we want our societies to improve; and what life do we envision for our citizens? The answer is clear: we want citizens to have both decent objective standards of living and feel subjectively satisfied with their lives. Researchers should therefore concentrate their efforts on the methods needed to collect and combine both objective and subjective data, rather than striving to establish the superiority of one type of data over the other.

We propose that a useful way to convey information on a wide array of subjective and objective indicators is to adopt a 'dashboard approach' to measurement. This approach does not attempt to reduce wellbeing to one number, but instead encourages researchers to find ways to present information on a variety of objective and subjective facets of wellbeing in an appealing and useful manner. Using such an approach will help educate both the public and policy-makers about what wellbeing really is, and about the multiple ways in which it can be cultivated.

It is an exciting time to be conducting research on the measurement of wellbeing. Advances made in the field over the past decades have brought about both a better understanding of what wellbeing is, and how it can be nurtured. As Robert Kennedy pointed out, we must continue to strive to measure "that which makes life worthwhile" (Kennedy, 1968, para. 22), and thus provide crucial information for policy-makers interested in fostering the welfare of citizens. Following Stiglitz's advice, scientists can help governments "do the right thing" by assisting them in measuring the right thing.

\section{Acknowledgements}

Funding for this project was generously provided by Eva Kedar, Ph.D.

\section{Authors}

Marie J. C. Forgeard

University of Pennsylvania

Eranda Jayawickreme

University of Pennsylvania \& Wake Forest University

Margaret L. Kern

University of Pennsylvania

Martin E. P. Seligman

University of Pennsylvania

seligman@psych.upenn.edu

\section{References}

Abramovitz, M., Scitovsky, T., \& Inkeles, A. (1973). Economic growth and its discontents. Bulletin of the American Academy of Arts and Sciences, 27, 11-27. http://dx.doi.org/10.2307/3822529

Alkire, S. (2002). Dimensions of human development. World Development, 30, 181-205. http://dx.doi.org/10.1016/S0305-750X(01)00109-7

Barrera, M., Sandler, I. N., \& Ramsay, T. B. (1981). Preliminary development of a scale of social support: Studies on college students. American Journal of Community Psychology, 9, 435-447. http://dx.doi.org/10.1007/BF00918174

Bauer, R. A. (Ed.) (1966). Social indicators. Cambridge, MA: MIT Press. 
Baumeister, R. (1992). Meanings in life. Hillsdale, NJ: Erlbaum.

Bentham, J. (1789/1996). Introduction to principles of morals and legislation. Oxford: Oxford University Press.

Boelhouwer, J., \& Stoop, I. (1999). Measuring well-being in the Netherlands: The SCP index from 1974 to 1997. Social Indicators Research, 48, 51-75. http://dx.doi.org/10.1023/A:1006931028334

Bonomi, A., Patrick, D., Bushnell, D., \& Martin, M. (2000). Validation of the United States' version of the World Health Organization Quality of Life (WHOQOL) instrument. Journal of Clinical Epidemiology, 53, 1-12. http://dx.doi.org/10.1016/S0895-4356(99)00123-7

Bradburn, N. (1969). The structure of psychological well-being. Chicago: Aldine.

Buhler, C. (1935). The curve of life as studied in biographies. Journal of Applied Psychology, 43, 653-673.

Camfield, L. (2005). Researching quality of life in developing countries. ESRC Research Group on Well-Being in Developing Countries newsletter, 3.

Carstensen, L. L., \& Cone, J. D. (1983). Social desirability and the measurement of psychological well-being in elderly persons. Journal of Gerontology, 38, 713-715.

Chamberlain, K., \& Zika, S. (1992). Stability and change in subjective well-being over short time periods. Social Indicators Research, 26, 101-117. http://dx.doi.org/10.1007/BF00304394

Chappell, T., \& Crisp, R. (1998). Utilitarianism. In E. Craig (Ed.), The Routledge Encyclopedia of Philosophy (Vol. 9, pp. 551-557). London: Routledge.

Chatzisarantis, N. L. D., Biddle, S. J. H., \& Meek, G. A. (1997). A self-determination theory approach to the study of intentions and the intention-behaviour relationship in children's physical activity. British Journal of Health Psychology, 2, 343-360.

Cohen, S., Underwood, L., \& Gottlieb, B. (2000). Social support measurement and intervention. New York: Oxford University Press.

Colby, A. \& Damon, W. (1992). Some do care: Contemporary lives of moral commitment. New York: Free Press.

Comim, F. (2005). Capabilities and happiness: Potential synergies. Review of Political Economy, LXIII, 161-176.

Crumbauch, J., \& Maholick, L. (1964). An experimental study in existentialism: The psychometric approach to Frankl's concept of noogenic neurosis. Journal of Clinical Psychology, 20, 200-207. http://dx.doi.org/10.1002/1097-4679(196404)20:2\%3c200::AID-JCLP2270200203\%3e3.0.CO;2-U

Csikszentmihalyi, M. (1975). Beyond boredom and anxiety. San Francisco, CA: Jossey-Bass.

Csikszentmihalyi, M. (1996). Finding flow: The psychology of engagement with everyday life. New York: Basic Books.

Csikszenmihalyi, M., \& Csikszenmihalyi, I. (1988). Optimal experience: Psychological studies of flow in consciousness. New York: Cambridge University Press.

Csikszentmihalyi, M., Larson, R., \& Prescott, S. (1977). The ecology of adolescent activity and experience. Journal of Youth and Adolescence, 6, 281-294. http://dx.doi.org/10.1007/BF02138940

Csikszentmihalyi, M., Rathunde, K., \& Whalen, S. (1997). Talented teenagers: The roots of success and failure. New York: Cambridge University Press.

Cutrona, C., \& Russell, D. (1987). The provisions of social relationships and adaptation to stress. In W. Jones \& D. Perlman (Eds.), Advances in personal relationships (pp. 37-67). Greenwich, CT: JAI Press.

Dasgupta, P. (2001). Human well-being and the natural environment. Oxford: Oxford University Press. http://dx.doi.org/10.1093/0199247889.001.0001

Deci, E. L., \& Ryan, R. M. (1980). Self-determination theory: When mind mediates behavior. Journal of Mind and Behavior, 1, 33-43.

Deci, E. L., \& Ryan, R. M. (1985). Intrinsic motivation and self-determination in human behavior. New York: Taylor \& Francis.

Deci, E. L., \& Ryan, R. M. (2000). The "what" and "why" of goal pursuits: Human needs and the selfdetermination of behavior. Psychological Inquiry, 11, 227-268. http://dx.doi.org/10.1207/S15327965PLI1104_01

Diener, E. (1995). A value based index for measuring national quality of life. Social Indicators Research, 36, 107127. http://dx.doi.org/10.1007/BF01079721

Diener, E. (2000). Subjective Well-Being: The science of happiness and a proposal for a national index. American Psychologist, 55, 34 - 43. http://dx.doi.org/10.1037/0003-066X.55.1.34

Diener, E. (2006). Guidelines for national indicators of subjective well-being and ill-being. Applied Research in Quality of Life, 10, 1-7.

Diener, E. (2009). Subjective Well-Being. In E. Diener (Ed.), The Science of Well-Being (Vol. 37, pp. 11-58). New York: Springer. http://dx.doi.org/10.1007/978-90-481-2350-6_2 
Diener, E., Emmons, R., Larsen, R., \& Griffin, S. (1985). The satisfaction with life scale. Journal of Personality Assessment, 49, 71-75. http://dx.doi.org/10.1207/s15327752jpa4901_13

Diener, E., Lucas, R., Schimmack, U., \& Helliwell, J. (2009). Well-being for public policy. New York: Oxford University Press. http://dx.doi.org/10.1093/acprof:oso/9780195334074.001.0001

Diener, E., Oishi, S., \& Lucas, R. E. (2003). Personality, culture, and subjective well-being: Emotional and cognitive evaluations of life. Annual Review of Psychology, 54, 403-425. http://dx.doi.org/10.1146/annurev.psych.54.101601.145056

Diener, E., Sandvik, E., \& Pavot, W. (1991). Happiness is the frequency, not the intensity, of positive versus negative affect. In F. Strack, M. Argyle \& N. Schwarz (Eds.), Subjective well-being: An interdisciplinary perspective (pp. 119-139). New York: Pergamon.

Diener, E., Sandvik, E., Pavot, W., \& Gallagher, D. (1991). Response artifacts in the measurement of subjective well-being. Social Indicators Research, 24, 35-56. http://dx.doi.org/10.1007/BF00292649

Diener, E., Scollon, C., \& Lucas, R. (2003). The evolving concept of subjective well-being. Advances in Cell Aging and Gerontology, 15, 187-219. http://dx.doi.org/10.1016/S1566-3124(03)15007-9

Diener, E., \& Seligman, M. (2004). Beyond money: Toward an economy of well-being. Psychological Science in the Public Interest, 5, 1-31. http://dx.doi.org/10.1111/j.0963-7214.2004.00501001.x

Diener, E., Suh, E. M., Lucas, R. E., \& Smith, H. L. (1999). Subjective well-being: Three decades of progress. Psychological Bulletin, 125, 276-302. http://dx.doi.org/10.1037/0033-2909.125.2.276

Diener, E., Wirtz, D., Tov, W., Kim-Prieto, C., Choi, D.-W., Oishi, S., \& Biswas-Diener, R. (2010). New wellbeing measures: Short scales to assess flourishing and positive and negative feelings. Social Indicators Research, 97, 143-156. http://dx.doi.org/10.1007/s11205-009-9493-y

Dolan, P., Peasgood, T., \& White, M. (2006). Review of research on the influences on personal well-being and application to policy making. London: DEFRA.

Dolan, P., \& White, M. P. (2007). How can measures of subjective well-being be used to inform public policy? Perspectives on Psychological Science, 2, 71-85. http://dx.doi.org/10.1111/j.1745-6916.2007.00030.x

Doyal, L., \& Gough, I. (1991). A theory of human need. London: MacMillan.

Easterbrook, G. (2003). The progress paradox: How life gets better while people feel worse. New York: Random House.

Easton, M. (2006). Britain's happiness in decline. http://news.bbc.co.uk/1/hi/programmes/happiness formula/4771908.stm

Ericsson, K. A. (2002). Attaining excellence through deliberate practice: Insights from the study of expert performance. In M. Ferrari (Ed.), The pursuit of excellence through education (pp. 21-55). Mahwah, NJ: Lawrence Erlbaum Associates.

Finnis, J. (1980). Natural law and natural rights. Oxford: Clarendon Press.

Finnis, J., Boyle, J.M., \& Grisez, G. (1987). Nuclear deterrence, morality and realism. Oxford: Clarendon Press.

Fleeson, W. (2007). Using experience sampling and multilevel modeling to study person-situation interactionist approaches to positive psychology. In A. D. Ong \& M. H. M. Van Dulman (Eds.). Handbook of methods in positive psychology (pp. 501-514). New York: Oxford University Press.

Fordyce, M. (1988). A review of research on The Happiness Measures: A sixty second index of happiness and mental health. Social Indicators Research, 20, 355-381. http://dx.doi.org/10.1007/BF00302333

Frankl, V. (1959). Man's search for meaning. Boston: Beacon Press.

Furr, R. M. (2009). Personality psychology as a truly behavioural science. European Journal of Personality, 23, 369-401. http://dx.doi.org/10.1002/per.724

GAO (2003). Forum on Key National Indicators: Assessing the nation's position and progress. Washington, D.C.: General Accounting Office.

Gasper, D. (2004). Human well-being: Concepts and conceptualizations. In M. McGillivray (Ed.), Measuring well-being. Helsinki, Finland: UNU-WIDER.

Gasper, D. (2010). Understanding the diversity of conceptions of well-being and quality-of-life. Journal of SocioEconomics, 39, 351-360. http://dx.doi.org/10.1016/j.socec.2009.11.006

German Institute for Economic Research (DIW). (2008). German Socio-Economic Panel Study - 2005 (Wave 2005). Berlin, Germany: Author.

Goodman, P. (September 23, 2009). Emphasis on growth is called misguided. New York Times.

Gottlieb, B. H., \& Bergen, A. E. (2010). Social support concepts and measures. Journal of Psychosomatic Research, 69, 511-520. http://dx.doi.org/10.1016/j.jpsychores.2009.10.001 
Haber, M., Cohen, J., Lucas, T., \& Baltes, B. (2007). The relationship between self-reported received and perceived social support: A meta-analytic review. American Journal of Community Psychology, 39, 133-144. http://dx.doi.org/10.1007/s10464-007-9100-9

Heckhausen, J., Wrosch, C., \& Schulz, R. (2010). A motivational theory of life-span development. Psychological Review, 117, 32-60. http://dx.doi.org/10.1037/a0017668

Hektner, J., Schmidt, J., \& Csikszentmihalyi, M. (2007). Experience sampling method: Measuring the quality of everyday life. Thousand Oaks, CA: Sage Publications.

Helson, R., \& Srivastava, S. (2001) Three paths of adult development: Conservers, seekers, and achievers. Journal of Personality and Social Psychology, 80, 995-1010. http://dx.doi.org/10.1037/0022-3514.80.6.995

Hills, P., \& Argyle, M. (2001). Happiness, introversion-extraversion and happy introverts. Personality and Individual Differences, 30, 595-608. http://dx.doi.org/10.1016/S0191-8869(00)00058-1

Huppert, F. A., Marks, N., Clark, A. E., Siegrist, J., Stutzer, A., \& Vittersø, J., (2006). Personal and social well-being module for the European Social Survey, Round 3. NC8 Paper 3b.

Huppert, F. A., Marks, N., Clark, A. E., Siegrist, J., Stutzer, A., Vittersø, J., \& Wahrendorf, M. (2008). Measuring well-being across Europe: Description of the ESS Well-being Module and preliminary findings. Working Paper No. 2008-40, Paris School of Economics.

Huppert, F. A., \& So, T. C. (2009). What percentage of people in Europe are flourishing and what characterises them? Paper prepared for the OECD/ISQOLS meeting "Measuring subjective well-being: An opportunity for NSOs?" Florence, July 23-24, 2009.

Jahoda, M. (1958). Current concepts of positive mental health. New York: Basic Books. http://dx.doi.org/10.1037/11258-000

Jayawickreme, E., \& Seligman, M. E. P. (2010). The engine of well-being. Unpublished manuscript.

Jung, C. G. (1933). Modern man in search of a soul. New York: Harcourt.

Kahneman, D. (1999). Objective happiness. In D. Kahneman, E. Diener \& N. Schwarz (Eds.), Foundations of hedonic psychology: Scientific perspectives on enjoyment and suffering (pp. 3-25). New York: Russell Sage Foundation.

Kahneman, D., \& Krueger, A. (2006). Developments in the measurement of subjective well-being. The Journal of Economic Perspectives, 20, 3-24. http://dx.doi.org/10.1257/089533006776526030

Kahneman, D., Krueger, A., Schkade, D., Schwarz, N., \& Stone, A. (2004). A survey method for characterizing daily life experiences: The day reconstruction method. Science, 306, 1776-1780. http://dx.doi.org/10.1126/science.1103572

Kahneman, D., Krueger, A., Schkade, D., Schwarz, N., \& Stone, A. (2006). Would you be happier if you were richer? A focusing illusion. Science, 312, 1908-1910. http://dx.doi.org/10.1126/science.1129688

Kasser, T., \& Ryan, R. M. (1993). A dark side of the American dream: Correlates of financial success as a central life aspiration. Journal of Personality and Social Psychology, 65, 410-422. http://dx.doi.org/10.1037/0022-3514.65.2.410

Kasser, T., \& Ryan, R. M. (1996). Further examining the American dream: Different correlates of intrinsic and extrinsic goals. Personality and Social Psychology Bulletin, 22, 280-287. http://dx.doi.org/10.1177/0146167296223006

Kennedy, R. (1968). Remarks of Robert F. Kennedy at the University of Kansas, March 18, 1968. http://www.jfklibrary.org/Historical+Resources/Archives/Reference+Desk/Speeches/RFK/RFKSpeech68Ma r18UKansas.htm

Keyes, C. L. M., Shmotkin, D., \& Ryff, C. D. (2002). Optimizing well-being: The empirical encounter of two traditions. Journal of Personality and Social Psychology, 82, 1007-1022. http://dx.doi.org/10.1037/0022-3514.82.6.1007

King, L. A., Hicks, J. A., Krull, J. L., Del Gaiso, A. K. (2006). Positive affect and the experience of meaning of life. Journal of Personality and Social Psychology, 90, 179-196. http://dx.doi.org/10.1037/0022-3514.90.1.179

King, L. A., \& Napa, C. K. (1998). What makes a life good? Journal of Personality and Social Psychology, 75, 156165. http://dx.doi.org/10.1037/0022-3514.75.1.156

Klerman, G., Lavori, P., Rice, J., Reich, T., Endicott, J.,...Hirschfield, R. M. A. (1985). Birth cohorts trends in rates of major depressive disorder among relatives of patients with affective disorder. Archives of General Psychiatry, 42, 689-693.

Kling, K. C., Seltzer, M. M., \& Ryff, C. D. (1997). Distinctive late-life challenges: Implications for coping and well-being. Psychology and Aging, 12, 288-295. http://dx.doi.org/10.1037/0882-7974.12.2.288 
Koestner, R., Losier, G. F., Vallerand, R. J., \& Carducci, D. (1996). Identified and introjected forms of political internalization: Extending self-determination theory. Journal of Personality and Social Psychology, 70, 10251036. http://dx.doi.org/10.1037/0022-3514.70.5.1025

Kuznets, S. (1933). National income. In E. Seligman \& A. Johnson (Eds.), Encyclopedia of the Social Sciences (Vol. 2). New York: Macmillan.

Kuznets, S. (1934). National income 1929-1392. Senate document No. 124, 73'rd US Congress.

Kuznets, S. (1948). Discussion of the new Department of Commerce income serioes: National income, a new version. Review of Economics and Statistics, 30, 151-179. http://dx.doi.org/10.2307/1926746

Land, K. (1996). Social indicators and the quality of life: Where do we stand in the mid-1990's? SINET, 45, 5-8.

Larson, R., \& Csikszentmihalyi, M. (1983). The Experience Sampling Method. New Directions for Methodology of Social E Behavioral Science, 15, 41-56.

Layard, R. (2005). Happiness: Lessons from a new science. London: Allen Lane.

Layard, R. (2010). Measuring subjective well-being. Science, 327, 534-535. http://dx.doi.org/10.1126/science.1186315

Lewis, K., \& Burd-Sharps, S. (2010). The measure of America, 2010-2011: Mapping risks and resilience. New York: New York University Press.

Locke, E. A., \& Latham, G. P. (2002). Building a practically useful theory of goal setting and task motivation: A 35-year odyssey. American Psychologist, 57, 705-717. http://dx.doi.org/10.1037/0003-066X.57.9.705

Lopes, P. N., Salovey, P., \& Straus, R. (2003). Emotional intelligence, personality, and the perceived quality of social relationships. Personality and Individual Differences, 35, 641-658. http://dx.doi.org/10.1016/S0191-8869(02)00242-8

Lucas, R. E., Clark, A. E., Georgellis, Y., \& Diener, E. (2004). Unemployment alters the set point for life satisfaction. Psychological Science, 15, 8-13. http://dx.doi.org/10.1111/j.0963-7214.2004.01501002.x

Lyubomirsky, S. (2008). The how of happiness: A scientific approach to getting the life you want. New York: The Penguin Press.

Lyubomirsky, S., \& Lepper, H. (1999). A measure of subjective happiness: Preliminary reliability and construct validation. Social Indicators Research, 46, 137-155. http://dx.doi.org/10.1023/A:1006824100041

Lyubomirsky, S., Sheldon, K. M., \& Schkade, D. (2005). Pursuing happiness: The architecture of sustainable change. Review of General Psychology, 9, 111-131. http://dx.doi.org/10.1037/1089-2680.9.2.111

Maslow, A. (1968). Toward a psychology of being. New York: van Nostrand.

Mayers, P. (1978). Flow in adolescence and its relation to school experience (Unpublished doctoral dissertation). University of Chicago, Chicago, IL.

McGregor, I., \& Little, B. (1989). Personal projects, happiness, and meaning: On doing well and being yourself. Journal of Personality and Social Psychology, 74, 494-512. http://dx.doi.org/10.1037/0022-3514.74.2.494

Michaelson, J., Abdallah, S., Steuer, N., Thompson, S., \& Marks, N. (2009). National accounts of well-being: Bringing real wealth onto the balance sheet. London: New Economics Foundation.

Mitchell, P. H., Powell, L., Blumenthal, J., Norten, J., Ironson, G.,...Berkman, L. F. (2003). A short social support measure for patients recovering from myocardial infarction: The ENRICHD Social Support Inventory. Journal of cardiopulmonary rehabilitation, 23, 398-403. http://dx.doi.org/10.1097/00008483-200311000-00001

Narayan-Parker, D. (2000). Crying out for change: Voices of the poor. Oxford and New York: Oxford University Press for the World Bank. http://dx.doi.org/10.1596/0-1952-1602-4

Negru, O. (2008). Personal goals: Structures and processes in adult development. Cogniție Creier Comportament, $12,265-283$.

Neugarten, B. L. (1968). The awareness of middle age. In B. L. Neugarten (Ed.), Middle age and aging (pp. 93-98). Chicago: University of Chicago Press.

Neugarten, B. L. (1973). Personality change in late life: A developmental perspective. In C. Eisodorfer \& M. P. Lawton (Eds.), The psychology of adult development and aging (pp. 311-335). Washington, D.C.: American Psychological Association. http://dx.doi.org/10.1037/10044-012

Nussbaum, M. (2007). Who is the happy warrior? Philosophy poses questions to psychology. Paper presented at the The Happiness and the Law Conference.

Nussbaum, M. C. (2000). Women and human development. Cambridge: Cambridge University Press.

Nussbaum, M. C. (2006). Frontiers of justice: Disability, nationality, species. Cambridge, MA: The Belknap Press.

Nussbaum, M.C. (1997). Cultivating humanity: A classical defense of reform in liberal education. Cambridge:

Cambridge University Press. 
Orth-Gomér, K., \& Undén, A.-L. (1987). The measurement of social support in population surveys. Social Science E Medicine, 24, 83-94. http://dx.doi.org/10.1016/0277-9536(87)90142-0

Parfit, D. (1984). Reasons and persons. Oxford: Clarendon Press.

Park, C. (2010). Making sense of the meaning literature: An integrative review of meaning making and its effect on adjustment to stressful life events. Psychological Bulletin, 136, 257-301. http://dx.doi.org/10.1037/a0018301

Pavot, W., \& Diener, E. (1993). The affective and cognitive context of self-reported measures of subjective wellbeing. Social Indicators Research, 28, 1-20. http://dx.doi.org/10.1007/BF01086714

Pavot, W., Diener, E., \& Suh, E. (1998). The temporal satisfaction with life scale. Journal of Personality Assessment, 70, 340-354. http://dx.doi.org/10.1207/s15327752jpa7002_11

Perlman, M., \& Marietta, M. (2005). The politics of social accounting: Public goals and the evolution of national accounts in Germany, the United Kingdom, and the United States. Review of Political Economy, 17, 211-230. http://dx.doi.org/10.1080/09538250500067262

Peterson, C. (2006). A primer in positive psychology. Oxford: Oxford University Press.

Phillips, D. (2006). Quality of life. London: Routledge.

Ranis, G., Stewart, F., \& Samman, E. (2006). Human development: Beyond the Human Development Index. Journal of Human Development, 7, 323-358. http://dx.doi.org/10.1080/14649880600815917

Rawls, J. (1971/1999). A theory of justice. Oxford: Oxford University Press.

Rawls, J. (2001). Justice as fairness: A restatement. Cambridge: Belknap Press.

Reis, H., \& Gable, S. (2000). Event-sampling and other methods for studying everyday experience. In H. Reis \& C. Judd (Eds.), Handbook of research methods in social and personality psychology (pp. 190-222). New York: Cambridge University Press.

Reis, H., \& Gable, S. (2003). Toward a positive psychology of relationships. In C. L. M. Keyes \& J. Haidt (Eds.), Flourishing: Positive psychology and the life well-lived. Washington, D.C.: American Psychological Association. http://dx.doi.org/10.1037/10594-006

Reis, H. T., Sheldon, K. M., Gable, S. L., Roscoe, J., \& Ryan, R. M. (2000). Daily well-being: The role of autonomy, competence, and relatedness. Personality and Social Psychology Bulletin, 26, 419-435. http://dx.doi.org/10.1177/0146167200266002

Riediger, M., \& Freund, A.M. (2004). Interference and facilitation among personal goals: Differential associations with subjective well-being and persistent goal pursuit. Personality and Social Psychology Bulletin, 30, 1511-1523. http://dx.doi.org/10.1177/0146167204271184

Robins, L., Helzer, J., Weissman, M., Orvaschel, H., Gruenberg, E.,...Regier, D. A. (1984). Lifetime prevalence of specific psychiatric disorders in three sites. Archives of General Psychiatry, 41, 949-958.

Rockett, J. R. \& Thomas, B. M. (1999). Reliability and sensitivity of suicide certification in higher-income countries. Suicide and Life Threatening Behavior, 29, 141-149.

Rogers, C. R. (1962). The interpersonal relationship: The core of guidance. Harvard Educational Review, 32, 416-429.

Ryan, R. M., \& Connell, J. P. (1989). Perceived locus of causality and internalization: Examining reasons for acting in two domains. Journal of Personality and Social Psychology, 57, 749-761. http://dx.doi.org/10.1037/0022-3514.57.5.749

Ryan, R. M., \& Deci, E. L. (2006). Self-regulation and the problem of human autonomy: Does psychology need choice, self-determination, and will? Journal of Personality, 74, 1557-1585. http://dx.doi.org/10.1111/j.1467-6494.2006.00420.x

Ryan, R. M., \& Deci, E. L. (2000). Self-determination theory and the facilitation of intrinsic motivation, social development, and well-being. American Psychologist, 55, 68-78. http://dx.doi.org/10.1037/0003-066X.55.1.68

Ryan, R. M., Huta, V., \& Deci, E. (2008). Living well: A self-determination theory perspective on eudaimonia. Journal of Happiness Studies, 9, 139-170. http://dx.doi.org/10.1007/s10902-006-9023-4

Ryan, R. M., Kuhl, J., \& Deci, E. L. (1997). Nature and autonomy: Organizational view of social and neurobiological aspects of self-regulation in behavior and development. Development and Psychopathology, 9, 701-728. http://dx.doi.org/10.1017/S0954579497001405

Ryan, R. M., Sheldon, K. M., Kasser, T., \& Deci, E. L. (1996). All goals are not created equal: An organismic perspective on the nature of goals and their regulation. In P. M. Gollwitzer \& J. A. Bargh (Eds.), The psychology of action: Linking cognition and motivation to behavior (pp. 7-26). New York: Guilford Press. 
Ryan, R. M., Stiller, J., \& Lynch, J. H. (1994). Representations of relationships to teachers, parents, and friends as predictors of academic motivation and self-esteem. Journal of Early Adolescence, 14, 226-249. http://dx.doi.org/10.1177/027243169401400207

Ryff, C. (1989). Happiness is everything, or is it? Explorations on the meaning of psychological well-being. Journal of Personality and Social Psychology, 57, 1069-1081. http://dx.doi.org/10.1037/0022-3514.57.6.1069

Ryff, C. D., \& Keyes, C. L. M. (1995). The structure of psychological well-being revisited. Journal of Personality and Social Psychology, 69, 719-727. http://dx.doi.org/10.1037/0022-3514.69.4.719

Ryff, C. D., \& Singer, B. H. (1996). Psychological well-being: meaning, measurement, and implications for psychotherapy research. Psychotherapy and Psychosomatics, 65, 14-23. http://dx.doi.org/10.1159/000289026

Ryff, C. D., \& Singer, B. H. (1998). The contours of positive human health. Psychological Inquiry, 9, 1-28. http://dx.doi.org/10.1207/s15327965pli0901 1

Ryff, C. D., \& Singer, B. H. (2002). Flourishing under fire: Resilience as a prototype of challenged thriving. In C. L. M. Keyes \& J. Haidt (Eds.), Flourishing: Positive psychology and the life well-lived. Washington, D.C.: American Psychological Association.

Ryff, C. D. (1995). Psychological well-being in adult life. Current Directions in Psychological Science, 4, 99-104. http://dx.doi.org/10.1111/1467-8721.ep10772395

Samman, E. (2007). A proposal for internationally comparable indicators of psychological and subjective wellbeing: OPHI Working Paper No. 5. Oxford: OPHI.

Schwartz, S. (1992). Universals in the content and structure of values: Theoretical advances and empirical tests in 20 countries. In M. Zanna (Ed.), Advances in Experimental Social Psychology (Vol. 25). Orlando, FL: Academic.

Schwarz, N., \& Clore, G. (1983). Mood, misattribution, and judgments of well-being: Informative and directive functions of affective states. Journal of Personality and Social Psychology, 45, 513-523. http://dx.doi.org/10.1037/0022-3514.45.3.513

Schwarz, N., \& Strack, F. (1999). Reports of subjective well-being: Judgmental processes and their methodological implications. In D. Kahneman, E. Diener \& N. Schwarz (Eds.), Foundations of hedonic psychology: Scientific perspectives on enjoyment and suffering (pp. 61-84). New York: Russell Sage Foundation.

Scollon, C., Kim-Prieto, C., \& Diener, E. (2007). Experience sampling: Promises and pitfalls, strengths and weaknesses. Journal of Happiness Studies, 4, 5-34. http://dx.doi.org/10.1023/A:1023605205115

Seidlitz, L., Abernethy, A. D., Duberstein, P. R., Evinger, J. S., Chang, T. H., \& Lewis, B. L. (2002). Development of the spiritual transcendence index. Journal for the Scientific Study of Religion, 41, 439-453. http://dx.doi.org/10.1111/1468-5906.00129

Seligman, M. (2002). Authentic Happiness. New York: Free Press.

Seligman, M. (2011). Flourish. New York: Simon \& Schuster.

Sen, A. K. (1993). Positional objectivity. Philosophy and Public Affairs 22, 126-145.

Sen, A. K. (1999). Development as freedom. New York: Anchor Books.

Sen, A. K. (2004). Elements of a theory of human rights. Philosophy and Public Affairs, 32, 315-356. http://dx.doi.org/10.1111/j.1088-4963.2004.00017.x

Sheldon, K. M., Elliot, A. J., Kim, Y., \& Kasser, T. (2001). What is satisfying about satisfying events? Testing 10 candidate psychological needs. Journal of Social and Personality Psychology, 80, 325-339. http://dx.doi.org/10.1037/0022-3514.80.2.325

Sheldon, K. M., Ryan, R. M., Deci, E. L., \& Kasser, T. (2004). The independent effects of goal content and motives on well-being: It's both what you pursue and why you pursue it. Personality and Social Psychology Bulletin, 30, 475-486. http://dx.doi.org/10.1177/0146167203261883

Shin, D. C., \& Johnson, D. M. (1978). Avowed happiness as an overall assessment of the quality of life. Social Indicators Research, 5, 475-492. http://dx.doi.org/10.1007/BF00352944

Smith, J., Fleeson, W., Geiselmann, B., Settersten Jr, R. A., \& Kunzmann, U. (2001). Sources of well-being in very old age. In P. Baltes \& K. U. Mayer (Ed.). The Berlin Aging Study: Ageing from 70 to 100 (pp. 450-471). Cambridge, UK: Cambridge University Press.

Steger, M., Frazier, P., Oishi, S., \& Kaler, M. (2006). The meaning in life questionnaire: Assessing the presence of and search for meaning in life. Journal of Counseling Psychology, 53, 80-93.

http://dx.doi.org/10.1037/0022-0167.53.1.80 
Steketee, M. (2011, January 22). We shouldn't judge wellbeing by GDP alone. The Australian. http://www.theaustralian.com.au/news/opinion/we-shouldnt-judge-wellbeing -by-gdp-alone/storye6frg6zo-1225992491496

Stiglitz, J., Sen, A., \& Fitoussi, J.-P. (2009). Report by the Commission on the Measurement of Economic Performance and Social Progress. Retrieved November 10, 2010 from http://www.stiglitz-senfitoussi.fr/documents/rapport_anglais.pdf

Strack, F., Martin, L., \& Schwarz, N. (1988). Priming and communication: Social determinants of information use in judgments of life satisfaction. European Journal of Social Psychology, 18, 429-442. http://dx.doi.org/10.1002/ejsp.2420180505

Taylor, S. E., Lerner, J. S., Sherman, D. K., Sage, R. M., \& McDowell, N. K. (2003). Portrait of the self-enhancer: Well adjusted and well liked or maladjusted and friendless? Journal of Personality and Social Psychology Bulletin, 84, 165-176. http://dx.doi.org/10.1037/0022-3514.84.1.165

Twenge, J. (2000). The age of anxiety? The birth cohort change in anxiety and neuroticism, 1952-1993. Journal of Personality and Social Psychology, 79, 1007-1021. http://dx.doi.org/10.1037/0022-3514.79.6.1007

UNDP (2010). The real wealth of nations: Pathways to human development. New York.

University of Essex. (2008). Institute for Social and Economic Research, British Household Panel Survey. Colchester, Essex: UK Data Archive.

Veenhoven, R. (2004). Happiness as a public policy aim: The greatest happiness principle. In A. P. Linley, \& S. Joseph (Eds.) Positive psychology in practice (pp. 658-678). Hoboken, NJ: John Wiley \& Sons Inc.

Wardell, J. (2011, January 10). Recession-weary Britons get happiness index. BusinessWeek. http://www.businessweek.com/ap/financialnews/D9KLDQL82.htm

Watson, D., Clark, L., \& Tellegen, A. (1988). Development and validation of brief measures of positive and negative affect: The PANAS. Journal of Personality and Social Psychology, 54, 1063-1070. http://dx.doi.org/10.1037/0022-3514.54.6.1063

Watson, N. (Ed). HILDA user manual-Release 5.0. Melbourne, Australia: Melbourne Institute of Applied Economic and Social Research, University of Melbourne.

Wheeler, L., \& Reis, H. (1991). Self-recordings of everyday life events: Origins, types, and uses. Journal of Personality, 59, 339-354. http://dx.doi.org/10.1111/j.1467-6494.1991.tb00252.x

Williams, G. C., Rodin, G. C., Ryan, R. M., Grolnick, W. S., \& Deci, E. L. (1998). Autonomous regulation and long-term medication adherence in adult outpatients. Health Psychology, 17, 269-276. http://dx.doi.org/10.1037/0278-6133.17.3.269

Worthington, E. L., Wade, N. G., Hight, T. L., Ripley, J. S., McCullough, M. E.,...O'Connor, L. (2003). The Religious Commitment Inventory-10: Development, refinement, and validation of a brief scale for research and counseling. Journal of Counseling Psychology, 50, 84-96. http://dx.doi.org/10.1037/0022-0167.50.1.84

Yalom, I. (1980). Existential psychotherapy. New York: Basic Books.

Zencey, E. (2009, August 9). G.D.P. R.I.P. New York Times. 